\title{
PENERAPAN METODE CLUSTERING PADA APLIKASI DASHBOARD HARGA PANGAN DI KOTA LUBUKLINGGAU
}

\author{
Rakhmad Kuswandhie ${ }^{1}$, Alfiarini ${ }^{2}$ \\ ${ }^{1}$ Program Studi Sistem Informasi STMIK Bina Nusantara Jaya Lubuklinggau \\ ${ }^{2}$ Program Studi Sistem Informasi STMIK Bina Nusantara Jaya Lubuklinggau \\ e-mail: ${ }^{1}$ ma2dxl@gmail.com, 2alfiarini3@gmail.com
}

\begin{abstract}
Abstrak
Masyarakat umum membutuhkan rujukan informasi harga pangan yang terpercaya sekaligus mudah diakses. Penelitian ini bertujuan membangun sebuah aplikasi dashboard harga pangan dengan metode clustering untuk mendukung kerja pengendalian inflasi daerah yang telah menjadi program pemerintah. Aplikasi ini dikembangkan dengan mengacu pada standar kebutuhan pemantauan harga pangan oleh Tim Pengendalian Inflasi Kota Lubuklinggau. Arsitektur aplikasi menggunakan clustering jenis pangan dan fluktuasi harga pangan dalam perubahannya yang nantinya digambarkan dalam bentuk grafik serta cluster berdasarkan wilayah. Sistem diharapkan dapat berjalan baik dalam menampilkan data harga per komoditas, statistik harga bulanan, metadata harga dan akses pengelolaan sistem oleh administrator. Aplikasi Dashboard Harga Pangan dengan metode clustering sebagai produk penelitian memberi kontribusi langsung bagaimana menyelesaikan pemantauan harga dari cara manual menggunakan struktur sistem database dan masyarakat akan mendapat informasi harga pangan secara real time. Arsitektur sistem menggunakan website untuk implementasi sistem data-sentral bertujuan untuk menekan biaya. Model ini dapat menjadi rujukan bagi sistem serupa yang membutuhkan suatu implementasi data sentral yang handal dan berbiaya murah.
\end{abstract}

Kata kunci : Harga Pangan; Grafik; Dashboard

\begin{abstract}
The general public needs a reliable and easily accessible reference to information on food prices. This study aims to build a food price dashboard application with the clustering method to support regional inflation control work which has become a government program. This application was developed with reference to the standard needs for monitoring food prices by the Lubuklinggau City Inflation Control Team. The application architecture uses food type clustering and food price fluctuations in changes which will later be described in graphs and clusters based on regions. The system is expected to run well in displaying price per commodity data, monthly price statistics, price metadata and access to system management by administrators. The Food Price Dashboard application with the clustering method as a research product provides a direct contribution to how to complete price monitoring from the manual method using a database system structure and the public will get real time food price information. The system architecture using the website for data-central system implementation aims to reduce costs. This model can be used as a reference for similar systems that require a reliable and low-cost central data implementation.
\end{abstract}

Keywords : Food Price; Graph; Dashboard 


\section{PENDAHULUAN}

Kebutuhan nformasi menjadi bagian yang penting bagi kehidupan manusia saat ini dikarenakan dapat memberi pengetahuan suatu hal serta digunakan untuk membantu manusia dalam proses pengambilan keputusan. Salah satu kebutuhan informasi mencakup dalam berbagai aspek, antara lain: dalam bidang $e$ government [1], dan kebutuhan informasi pangan [2]. Pangan dapat dikatakan sebagai salah satu kebutuhan dasar manusia yang pemenuhannya sebagai suatu keharusan, tidak dapat ditunda dan juga tidak dapat disubstitusi dengan bahan lain. Ketersediaan pangan menyangkut masalah produksi, stok, impor dan ekspor, yang harus dikelola sedemikian rupa, sehingga walaupun produksi pangan sebagian bersifat musiman, terbatas dan tersebar antar wilayah, pangan yang tersedia bagi keluarga harus cukup volume dan jenisnya, serta stabil dari waktu ke waktu. Sementara itu subsistem distribusi mencakup upaya memperlancar proses peredaran pangan antar wilayah dan antar waktu serta stabilitas harga pangan.

\section{Dinas Ketahanan Pangan Kota} Lubuklinggau merupakan salah satu instansi Pemerintahan di lingkungan Kota Lubuklinggau yang membidangi lingkup tanaman pangan, pertanian, perkebunan dan kehutanan. Dalam mendapatkan harga pangan yang ada di Kota Lubuklinggau biasanya diperoleh melalui survei yang dilakukan oleh petugas lapangan dan dilaporkan setiap minggunya, pada tahapan penyampaian hasil, sering mengalami keterlambatan dikarenakan data tersebut harus diolah melalui aplikasi perkantoran yang menyita waktu.

Didasarkan dari permasalahan yang ada maka dibutuhkan suatu sistem yang dapat digunakan untuk menampilkan harga pangan secara real time. Dalam penerapannya, sistem informasi harga pangan dapat menentukan kebijakan tentang pengendalian inflasi daerah [3], Sistem ini sering disebut dengan sistem Dasboard. Dashboard menampilkan setiap data ke dalam bentuk yang representatif sehingga mudah untuk dicerna. Biasanya dashboard dapat berupa tampil grafik [4], tabel [5], maupun diagram [6]. Dalam hal pengolahan data harga pangan, tentunya dibutuhkan pengelompokkan data harga pangan berdasarkan wilayah-wilayah tertentu. Metode klasterisasi dapat diterapkan pada sistem ini. Metode klasterisasi dapat menentukan drajat keanggotaan dan kemudian menggunakannya dengan memasukkan ke dalam elemen data menjadi suatu kelompok/ klaster [7], [8], [9].

Tujuan dalam penelitian ini adalah membangun aplikasi berbasis web harga pangan di Kota Lubuklinggau dengan metode clustering pada proses pengolahan data yang direpresentasikan kedalam bentuk dashboard sebagai sebuah informasi yang dapat digunakan baik instansi dinas maupun oleh masyarakat.

\section{TINJAUAN PUSTAKA}

\subsection{Dashboard}

Dashboard merupakan tampilan visual untuk menyampaikan informasi yang paling penting dan dibutuhkan dalam mencapai tujuan [10]. Informasi tersebut digabung dan diatur pada satu layar sehingga informasi dapat dipantau secara sekilas. Informasi yang disampaikan pada dashboard berupa kombinasi antara tulisan dan gambar, sehingga mampu berkomunikasi dengan efisien.

\subsection{Harga}

Harga adalah sebuah nilai yang ditukarkan pelanggan dengan manfaat dari memiliki atau menggunakan produk atau jasa yang nilainya ditetapkan oleh pembeli atau penjual 
dan ditetapkan oleh penjual untuk suatu harga yang sama terhadap semua pembeli [11].

\subsection{Clustering}

Clustering adalah proses membuat pengelompokan sehingga semua anggota dari setiap partisi mempunyai persamaan berdasarkan matrik tertentu, sebuah klaster adalah sekelompok kumpulan objek yang digabung bersama karena persamaan atau kedekatannya [7].

\section{$2.4 \quad$ PHP}

PHP (Hypertext Preprocessor) adalah bahasa server-side-scripting yang menyatu dengan HTML untuk membuat halaman web yang dinamis. Halaman web dinamis adalah jenis web yang content / isinya dapat berubah-ubah setiap saat. PHP (Hypertext Preprocessor) adalah bahasa pemrograman yang berjalan dalam sebuah webserver dan berfungsi sebagai pengolah data pada sebuah server [12].

\subsection{MySQL}

MySQL adalah salah satu jenis database server yang sangat terkenal dan banyak digunakan untuk membangun aplikasi web yang menggunakan database sebagai sumber dan pengelolaan datanya [12].

\section{METODOLOGI PENELITIAN}

Metode yang digunakan dalam pengembangan sistem yaitu metode Waterfall, dikarenakan langkah-langah metode Waterfall sesuai dengan rancangan peneliti. Dimana dalam pengembangan ini peneliti merancang dan membangun sistem secara bertahap. Tahapan metode Waterfall dapat dilihat pada gambar 1 berikut.

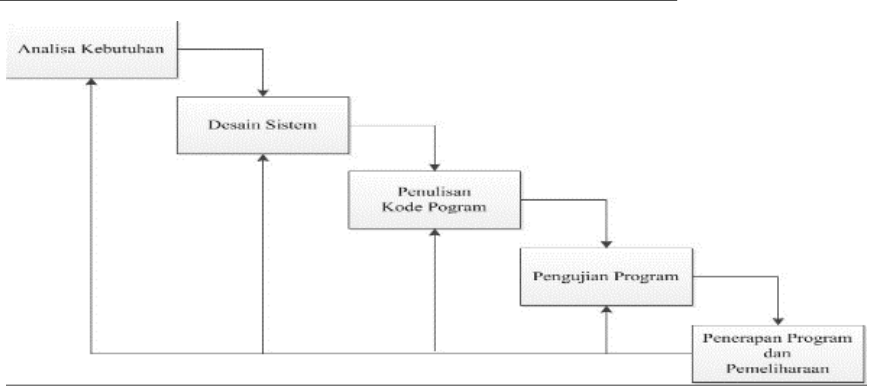

Gambar 1. Waterfall Model

1. Pengumpulan kebutuhan

Pada tahap ini dilakukan penelitian langsung ke tempat penelitian dan wawancara dengan Dinas terkait (Dinas Ketahanan Pangan) di Kota Lubuklinggau untuk mencari permasalahan yang berhubungan dengan permasalahan harga pangan di Kota Lubuklinggau.

2. Desain Sistem

Pada tahap ini peneliti membuat desain dari sistem yang dibuat berupa struktur data, arsitektur perangkat lunak menggunakan Use Case Diagram, dan representasi antarmuka yang diimplementasikan menjadi program pada tahap selanjutnya.

Use Case Daigarm berfungsi untuk menggambarkan dan memodelkan serta mengorganisasi aplikasi dashboard harga pangan dikota lubuklinggau, dimana pembuatan diagram ini terdiri dari 2 aktor yaitu admin dan Kepala Dinas. Alur Use Case Dashboard harga pangan di Kota Lubuklinggau dapat dilihat pada gambar 2 berikut:

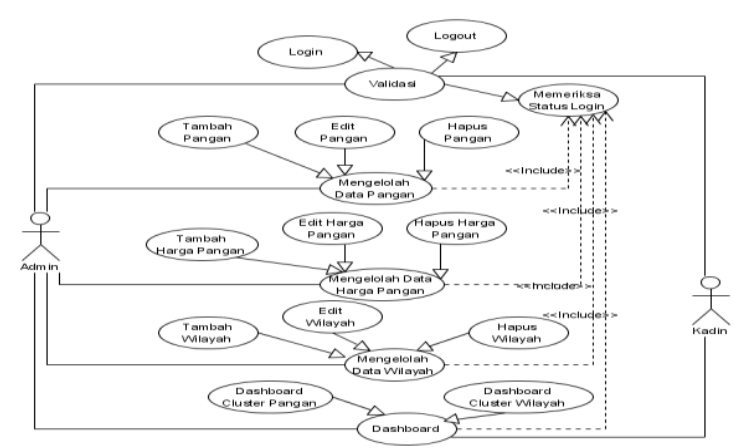

Gambar 2. Use Case Diagram 
3. Pembuatan Kode Program

Pada proses ini, peneliti melakukan kegiatan pembuatan kode program (coding), untuk membuat program atau aplikasi yang sesuai dengan desain sistem sebelumnya. Hasil dari tahap ini adalah aplikasi dashboard harga pangan di Kota Lubuklinggau yang sesuai dengan desain yang telah dibuat pada tahap desain.

4. Pengujian sistem

Kegiatan pengujian program dilakukan untuk melihat apakah system atau aplikasi yang dibuat masih terdapat kesalahan baik alur dan logika pemrogramannya serta untuk melihat apakah fungsi-fungsi ada dalam sistem berjalan sebagai mana mestinya.

\section{HASIL DAN PEMBAHASAN}

Sistem dashboard pengolahan harga pangan dengan menggunakan metode clustering ini mengelompokkan harga pangan berdasarkan wilayah yang ada di Kota Lubuklinggau. Sistem ini terdiri dari dua user utama, yaitu: admin dan Kadin.

\subsection{User Interface}

User interface dapat dideskripsikan sebagai tampilan layout dari keseluruhan sistam yang digunakan oleh seluruh user. Admin memegang peranan penting dalam keseluruhan sistem, sedangkan output berupa tampilan dashboard yang dilihat oleh Kadin maupun masyarakat. Tampilan menu admin antara lain: menu login admin, menu data pangan, menu data wilayah, dan menu harga pangan.

\section{Menu Login}

Menu login digunakan oleh admin untuk masuk ke halaman utama user. Untuk masuk ke menu utama dibutuhkan akses login dengan memasukkan username dan password. Gambar 2 menunjukkan tampilan layout menu login admin.

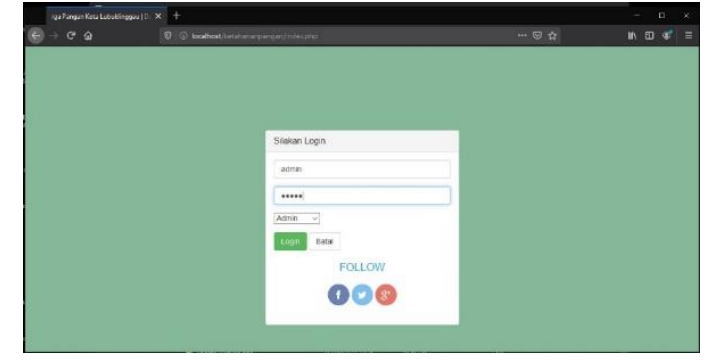

Gambar 3. Tampilan menu login admin

2 Menu Halaman Utama

Setelah admin memasukkan username dan password dengan benar, maka sistem menampilkan halaman utama admin. Gambar 3 menunjukkan tampilan layout menu halaman utama.

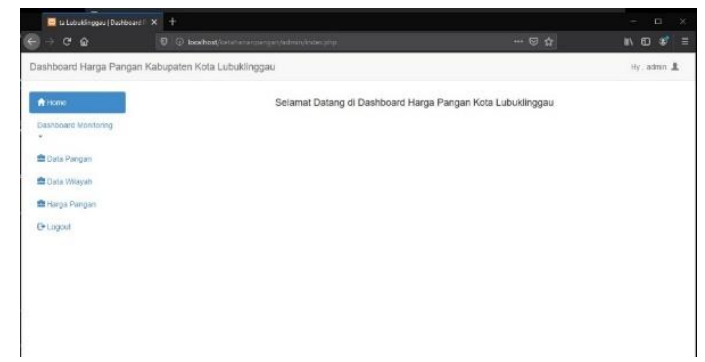

Gambar 4. Tampilan menu halaman utama

3 Menu Data Pangan

Menu halaman digunakan admin untuk melakukan penginputan data pangan. Admin dapat melakukan tambah data, edit data, dan delete data. Gambar 4 menunjukkan tampilan layout menu halaman data pangan.

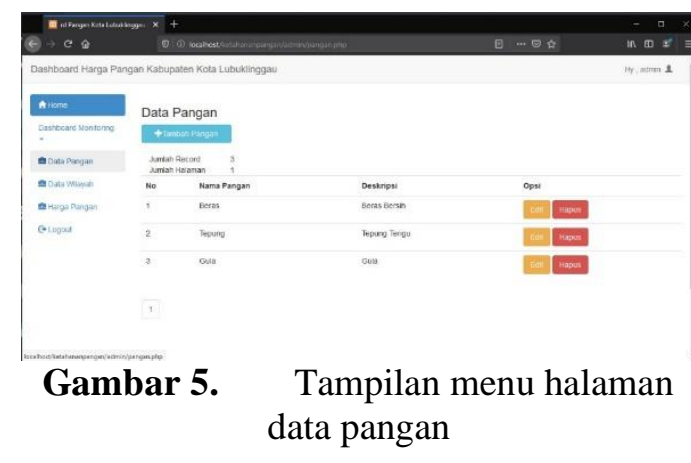


4 Menu Data Wilayah

Menu data wilayah digunakan admin untuk melakukan penginputan data wilayah. Admin dapat melakukan tambah data, edit data, dan delete data. Gambar 5 menunjukkan tampilan layout menu halaman data wilayah.

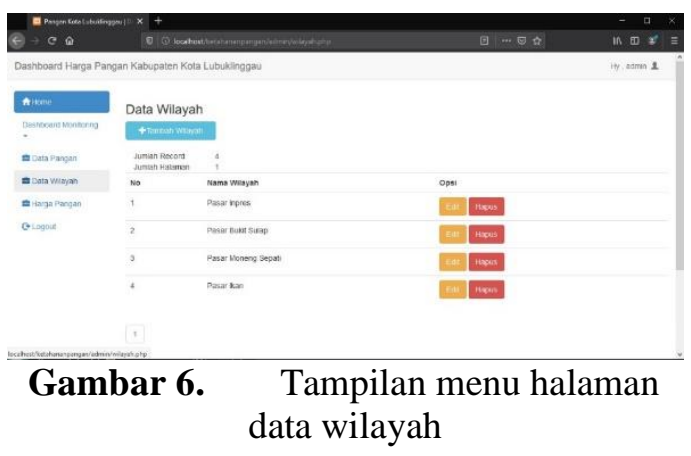

\section{$5 \quad$ Menu Input}

Menu input digunakan oleh admin untuk melakukan input data ke dalam sistem. Menu input harga pangan digunakan untuk melakukan input harga pangan perwilayah. Gambar 6 menunjukkan tampilan layout menu input harga pangan.

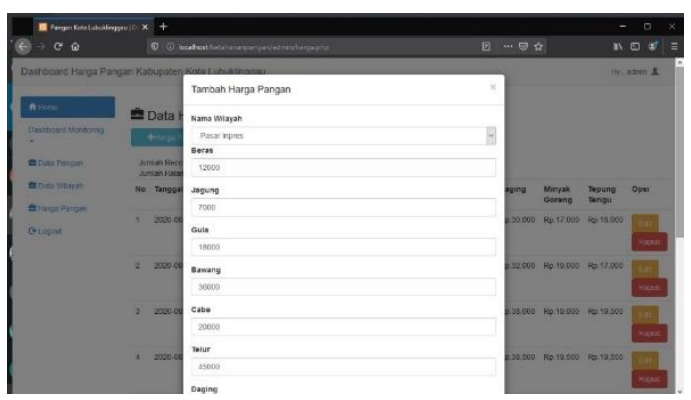

Gambar 7. Tampilan menu halaman input harga pangan

6 Menu Output

Menu output merupakan tampilan hasil dari pengolahan data yang telah dilakukan penginputan oleh admin.

a. Menu Output Data Harga Pangan

Menu ini menampilkan harga pangan yang telah di inputkan oleh admin. Gambar 7 menampilkan layout menu output harga pangan.

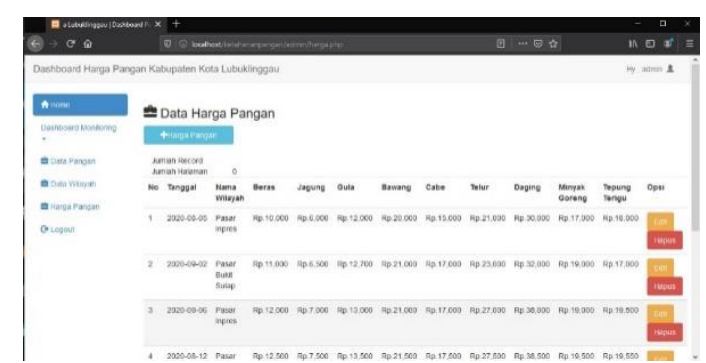

Gambar 8. Tampilan menu halaman output harga pangan

b. Menu Output Dashboard

Menampilkan tampilan grafis dari fluktuasi harga pangan per wilayah. Gambar 8 dan gambar 9 menampilkan layout dashboard harga pangan.

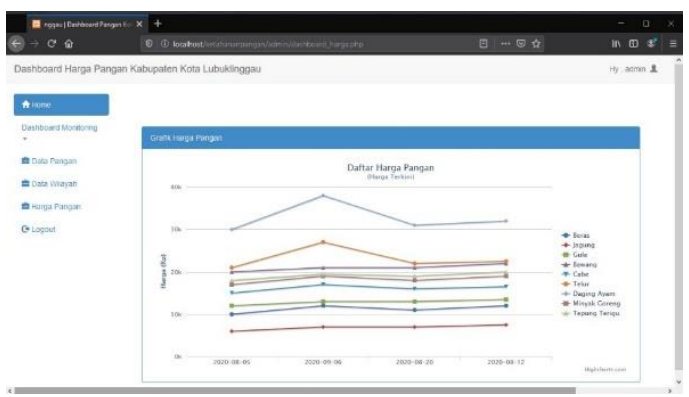

Gambar 9. Tampilan menu halaman dashboard

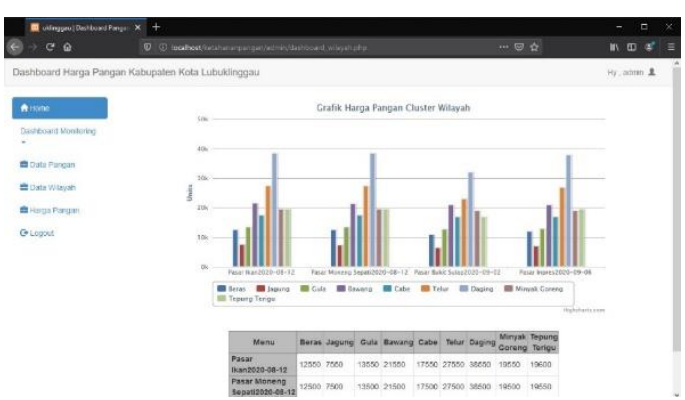

Gambar 10. Tampilan menu halaman dashboard perwilayah

\section{KESIMPULAN}

Dari pembahasan terhadap system dashboard harga pangan di Kota Lubuklinggau, dapat disimpulkan bahwa sistem berhasil menampilkan grafis harga pangan. Admin memasukkan daftar harga pangan per minggu dan data ditampilkan dalam bentuk grafik fluktuasi harga pangan baik perminggu atau perbulannya. 
Clusterisasi data memungkinkan data dikelompokkan ke perwilayah, dalam hal ini wilayah pasar yang ada di Kota Lubuklinggau, yakni: pasar bukit sulap, pasar inpres, pasar moneng sepati, dan pasar ikan. Hasil perancangan sistem ini menjawab kebutuhan informasi harga pangan di Kota Lubuklinggau yang dapat di akses oleh Kadin maupun masyarakat Lubuklinggau.

\section{SARAN}

Kepada semua pihak yang berniat untuk mengadakan penelitian dengan tema serupa, disarankan untuk memberikan tambahan antara lain:

1. Pengembangan sistem langsung terintegrasi dengan tampilan android.

2. Update data digunakan per hari, sehingga keakuratan datanya meningkat.

\section{DAFTAR PUSTAKA}

[1] P. H. Parsaorantua, Y. Pasoreh, and S. A. Rondonuwu, "Implementasi Teknologi Informasi Dan Komunikasi (Studi Tentang Web EGovernment Di Kominfo Kota Manado)," Acta Diurna, vol. VI, no. 3, pp. 1-14, 2017.

[2] A. Finandhita and O. M. Wibowo, "Visualisasi Data Harga Komoditas Pangan (Studi Kasus: Website Dinas Tanaman Pangan Dan Hortikultura Provinsi Jawa Barat)," Komputa J. Ilm. Komput. dan Inform., vol. 7, no. 2, pp. 59-68, 2018, doi: 10.34010/komputa.v7i2.3038.

[3] R. Rahman and S. Wahyuni, "Desain Sistem Informasi Harga Pangan Realtime Sebagai Instrumen Kebijakan Pengendalian Inflasi Daerah," J. Insypro (Information Syst. Process., vol. 2, no. 2, pp. 1-9, 2017 , doi: 10.24252/insypro.v2i2.4067.

[4] D. Trisnawarman, Z. Rusdi, P. Studi, S. Informasi, F. T. Informasi, and U. Tarumanagara, "Desain Dashboard Untuk Pendukung Sistem Cerdas Analisis Kesesuaian Kebutuhan dan Ketersediaan Sumberdaya Pembangunan Desa Mandiri," vol. 1, pp. 14-22, 2018.

[5] I. P. Putera and I. G. B. B. Dharma, "Pengembangan Sistem Informasi Manajemen Dashboard untuk Monitoring Kondisi Aset Berbasis Web ( Studi Kasus di Departemen Teknik Mesin dan Industri Universitas Gadjah Mada )," pp. 20 29, 2016.

[6] Triono, Z. Hakim, and R. Amelia, "Perancangan Aplikasi Dashboard Pengelolaan Hasil Produksi Departemen Finishing Berbasis Web Pada PT Panarub Industry," Sisfotek Glob., vol. 8, no. 2, pp. 84-89, 2018.

[7] E. Hadinata, "Simulasi Sistem Pendukung Keputusan Menggunakan Metode Klustering Algoritma Fuzzy c -Means," pp. 401-409, 2016.

[8] L. H. Fadly and S. Winiarti, "Sistem Penentuan Nutrisi Balita Dengan Metode Fuzzy C-Means Berdasarkan Produk Kemasan Berbasis Mobile," no. 1300018058 , pp. 1-12, 2018.

[9] M. A. W. K. MURTI, "Penerapan metode K-means clustering untuk mengelompokan potensi produksi buah - buahan di provinsi daerah istimewa yogyakarta," Universitas Sanata Dharma, Yogyakarta, 2017.

[10] R. Hermansyah and S. Herliani, "Penetapan Key Performance Indicator untuk Model Dashboard Monitoring Layanan Pengadaan Barang Diskominfo Jawa Barat," in Knsi 2018, 2018, pp. 1370-1375. 
[11] E. Dewi and S. Tarigan, "Pengaruh Gaya Hidup, Label Halal dan Harga Terhadap Keputusan Pembelian Kosmetik Wardah Pada Mahasiswa Program Studi Manajemen Fakultas Ekonomi Universitas Medan Area Medan," J. Konsep Bisnis dan Manaj., vol. 3, no. 1, pp. 1-15, 2016.

[12] M. Arief, Pemrograman Web Dinamis Menggunakan PHP dan MYSQL. Yogyakarta, Indonesia: Penerbit Andi, 2011. 